\title{
Interest Arousal by Haptic Feedback During a Storytelling for Kindergarten Children
}

\author{
Mina Shibasaki $\left.{ }^{1(}\right)$, Youichi Kamiyama ${ }^{1}$, Elaine Czech $^{1}$, \\ Koichi Obata $^{2}$, Yusuke Wakamoto ${ }^{2}$, Keisuke Kishi ${ }^{2}$, \\ Takayuki Hasegawa $^{2}$, Shinkuro Tsuchiya ${ }^{3}$, Soichiro Matsuda ${ }^{4}$, \\ and Kouta Minamizawa ${ }^{1}$ \\ ${ }^{1}$ Keio University Graduate School of Media Design, Yokohama, Japan \\ mina0415@kmd.kelo.ac.jp \\ 2 Toppan Printing Co., Ltd., Tokyo, Japan \\ ${ }^{3}$ Froebel-Kan Co., Ltd., Tokyo, Japan \\ ${ }^{4}$ University of Tsukuba, Tsukuba, Japan
}

\begin{abstract}
In this paper, we introduce "Kinder BURU BURU cushion" a vibrotactile cushion that is used during storytelling time to grab the attention of children to help them to focus on the story. We conducted field tests using our system, which confirmed that children were more interested in a story when using our system compared to normal storytelling. For this research, we collaborated with a printing company and a picture book company, designed our system based on user studies at a kid's space, and conducted empirical field experiments.
\end{abstract}

Keywords: Haptics · Embodied interaction - Storytelling · Edu-tech ·

Behavior analysis of children

\section{Storytelling and Embodied Interaction}

Vygotsky and Bandura [5] stated that the physicality of words and gestures should also be considered as types of tools for interaction for children. They believed communicating with other people was one method to help a child develop. A picture book is one example of a tool that helps children to gain verbal ability through communication with adults. It has been confirmed that children are able to learn languages from adults through picture books [1, 2]. Moreover, according to Bruner [6], the phenomenon of joint attention is how children display empathy for others. Bruner's infant study suggested that from an early age, children actively use their bodies to engage with others. Thus, collaborative interaction plays an essential role in the child's development for the child to understand themselves and others. Therefore, storytelling events at libraries and kids' spaces are beneficial to a child's development as they encourage collaborative interaction. However, the primary way that children explore the world using their bodies is through touch. As a result, educators, such as Frobel [3] and Montessori [4], attempted to demonstrate how interacting with "things" was essential for child development. Frobel [3], for example, founded a kindergarten that used the "Gifts," or educational play materials, to encourage children to learn while playing 
freely with objects. Montessori [4], similarly, developed teaching tools that trained a child's senses. Reggio Emilia [7] took this notion further by introducing the importance of creativity and developed a preschool education method that stressed physical learning through art expression. Iverson et al. [9, 10] and Antle et al. [11] also showed that exploratory activity that allowed a child to use their body influenced the depth of their understanding. By utilizing human physicality, especially one's tactile sense, the brain is more actively stimulated, which can help comprehension. Therefore, many museums have incorporated hands-on [8] activities to encourage a deep understanding of exhibits, particularly exhibitions related to cultural properties. Already there are many studies in which tactile technology has been adapted to children's education. Several of which focus on storytelling and reading. Yannier [12] et al. and Zhao et al. [13] verified that children reading with a vibrotactile tablet could achieve a deeper understanding of the content they were reading. However, a limitation to these studies was that they focused on individual or one-on-one readers. Through this research, we hope to explore how to focus children's interest in picture books in a group reading setting. During storytelling time, at public spaces like the library or kid space, children of various backgrounds listen to a story together. However, there are usually differences in age, the ability of understanding, and the interest level of the children. Also, there is a field problem that it was difficult to grab children's attention all of them because children's attention was different when long storytelling. As a result, selecting a picture-book that is suitable for everyone is a difficult task. In this study, we aimed to design experience to grab children's attention to picture books when multiple children listen to storytelling together. In the next chapter, we did fieldwork to explore the issue of a typical kindergarten setting and to find what interaction needed to make the system. Based on this result we developed a cushion that multiple children can feel picture book world through their body by haptic feedback same time. And then we conducted experiment to verification the effective of this system, and we analyzed children behavior to use behavior psychology method. Finally, we discussed what value the embodied experience of picture book could provide to children.

\section{Design}

\subsection{Fieldwork and Proposed Method}

We interviewed stakeholders, such as storytelling staff, to explore the issues of a typical kindergarten setting (The Froebel-Kan staff who worked in kindergarten and public library staff). Also, we observed children playing in a kid's space operated by FrobelKan as well as the storytelling activity provided by them. As a result, we found that staff tended to continually choose the same books because finding books that will interest all the children was difficult. Also, the books selected were one's that sold many copies as this aligned with the books parents were choosing to read to their children. In other words, there was a lack of diversity in the range of picture book experiences being introduced to the children. Additionally, based on our observations of the kid's space, fewer children were interested in the picture books than those that played with the play equipment and toys. Furthermore, during the storytelling activity, 
a large number of children got bored immediately, as opposed to those who retained interest in the picture book. Thus, we proposed the following system to get children interested in the story of picture books as in Fig. 1.

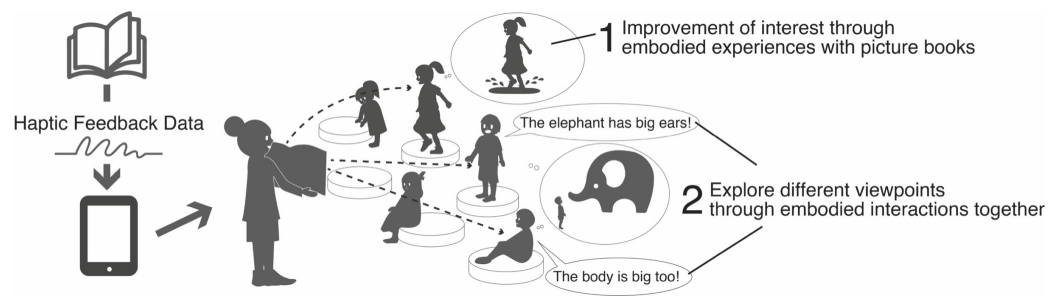

Fig. 1. Concept design of "Kinder BURU BURU Cushion"

\section{Improvement of Interest Through Embodied Experiences with Picture Books}

As shown in previous studies, children use their bodies to explore objects and phenomena. Such learning methods have proven to be successful for expanding interest and deepening understanding. We thought it is possible to use such methods during storytelling in the kindergarten. To make children think about the story beyond the words on the page, we needed to help them embody the actions of the story.

2. Explore Different Viewpoints Through Embodied Interactions Together

We thought if children can share their interests with each other, this would help expand their perspective of others. Allowing them to enjoy picture books more collectively. We decided to use a cushion, because if it were a wearable device, the operational costs would be too high. By simply sitting on the cushion it was possible for multiple users to experience the tactile sensations of the picture book all together.

\subsection{Hardware Design and Haptic Design}

We designed the configuration to satisfying our concept as in Fig. 2. We used a PC or tablet device uploaded with the tactile data for each picture book, and then transmitted the tactile data with a transmitter. The tactile data was received by multiple receivers and multiple Vibro-transducers (Acouve Co., Ltd./Vp6) operating all at same time. We created the transmit module and receive module. These modules could send and receive tactile information without cables by using wireless audio unit PLL synthesizer (Circuit Design, Inc./WA-TX-03, WA-RX-03). We also created the Haptic amp, and equipped it with a battery to eliminate cable. We then created corresponding haptic experiences for five picture books published by Froebel-Kan Co.,Ltd. In creating our haptic experiences, we did haptic design in the following process: First, we made haptic design storyboard to consider listener's perspective (subjectivity or objectivity). Second, we selected vibration from instrument sample data in Abltone (Ableton Co., Ltd.). For example, in the scene where a bear hit a tree, we used instruments such as drum kicks. We mainly used percussion instruments samples and rhythms to explain the 
body sensation of character. (Footsteps of characters, feeling of character knocked on the door etc.). Because percussion instruments could feel vibration clearly by our system. Finally, we adjusted the volume of all the contents to balance the vibrations, especially we strengthened data below $20 \mathrm{~Hz}$. We aimed to put at least one sensation on each page to prevent the children from getting bored.
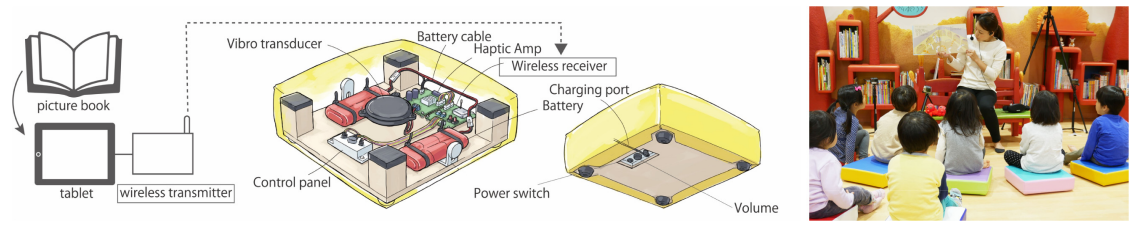

Fig. 2. System design and implementation

\section{Validation}

We conducted experiment to verification the effective of this system. Drew et al. [17] reported haptic feedback can draw children's attention and conversation about the sensation explain in picture book between parents and children. Therefore, we thought if children get information through the sensation, children's behavior like attention to the picture book and sitting on the cushion will change. For our study, we compared storytelling using our "BURU BURU" cushion and normal storytelling. And we analyzed children behavior to use behavior psychology method. The test was performed in four groups over two days $(\mathrm{am} / \mathrm{pm})$, and we analyzed what changes occurred in the children's behavior.

\subsection{Experimental Method}

\section{Participants}

Participants were recruited using flyers in a kid space operated by Froebel-Kan Co., Ltd. For the first test, we recruited a total of 10 children and their parents, 6 children in the morning ( 3 boys and 3 girls, aged 3 years) and 4 children in the afternoon ( 2 boys and 2 girls, aged 3 years) on July 23th 2019. In the second test, we recruited a total of 21 children and their parents, 10 pairs of children and parents in the morning ( 4 boys and 6 girls, aged 3-4 years) and 11 pairs of children and parents in the afternoon (6 boys and 5 girls, aged 3-4 years) on October 19th 2019. Participants were paid 3,000 JPY per hour for their participation. The total 31 children (average aged: 43.4 months) were used for the analysis, excluding those who were absence or attendees who joined in midway. Additionally, parents were asked to complete a questionnaire: "How many picture books do you read a week?" to help us gauge the participating children's existing level of familiarity with picture books. The majority, 21 people, answered that they read picture books every day. On the other hand, two participants stated that they rarely read picture books. The remaining eight people said they read picture books a few days a week. Overall, many of the children who participated were familiar with picture books. 
Testing was performed in a kid's space operated by Froebel-Kan Co., Ltd. We had children sit on the cushions as picture books were read aloud. We alternated between normal storytelling and storytelling with the system (see Table 1). We switched the order (with and without) between morning test and afternoon test to prevent preference bias due to the ordering. Also, we told parents to not stop a child should they decide to move off the cushion. Children were free to come and go as they wanted. Between the second and third storytelling we put in a brief exercise play break. In total, four picture books were read per group. For each test we captured each child's face on video.

Table 1. Summary of procedure

\begin{tabular}{|c|c|c|c|c|c|c|}
\hline \multicolumn{2}{|c|}{ Order of storytelling and Title } & & \multicolumn{4}{|c|}{$\begin{array}{l}\text { With or Without vibrotactile representation } \\
\text { (Time of storytelling) }\end{array}$} \\
\hline & & & $\begin{array}{l}\text { 7.23.am } \\
\text { Group A }\end{array}$ & $\begin{array}{l}\text { 7.23.pm } \\
\text { Group B }\end{array}$ & $\begin{array}{l}\text { 10.19.am } \\
\text { Group C }\end{array}$ & $\begin{array}{l}10.19 . p m \\
\text { Group D }\end{array}$ \\
\hline $\begin{array}{l}\begin{array}{l}\text { First } \\
\text { book }\end{array} \\
\end{array}$ & $\begin{array}{l}\text { Train of } \\
\text { Heteroconger hassi }\end{array}$ & $\begin{array}{l}\text { Written by Kenta Ostuka } \\
\text { Illustrate by Minako Kusaka }\end{array}$ & $\begin{array}{l}\text { With } \\
(05: 45)\end{array}$ & $\begin{array}{l}\text { Without } \\
(04: 00)\end{array}$ & $\begin{array}{l}\text { With } \\
(04: 30)\end{array}$ & $\begin{array}{l}\text { Without } \\
(04: 00)\end{array}$ \\
\hline \multirow[t]{2}{*}{$\begin{array}{l}\text { Second } \\
\text { book }\end{array}$} & $\begin{array}{l}\text { Hurry up!Train of } \\
\text { Heteroconger hassi } \\
(2019.07 .23)\end{array}$ & $\begin{array}{l}\text { Written by Kenta Ostuka } \\
\text { Illustrate by Minako Kusaka }\end{array}$ & \multirow[t]{2}{*}{$\begin{array}{l}\text { Without } \\
(04: 30)\end{array}$} & \multirow[t]{2}{*}{$\begin{array}{l}\text { With } \\
(04: 30)\end{array}$} & \multirow[t]{2}{*}{$\begin{array}{l}\text { Without } \\
(03: 00)\end{array}$} & \multirow[t]{2}{*}{$\begin{array}{l}\text { With } \\
(03: 15)\end{array}$} \\
\hline & $\begin{array}{l}\text { Kinder } \\
\text { book }(2019.10 .19)\end{array}$ & & & & & \\
\hline $\begin{array}{l}\text { Third } \\
\text { book }\end{array}$ & Nekozakana's egg & Yuichi Watanabe & $\begin{array}{l}\text { With } \\
(06: 30)\end{array}$ & $\begin{array}{l}\text { Without } \\
(05: 00)\end{array}$ & $\begin{array}{l}\text { With } \\
(06: 45)\end{array}$ & $\begin{array}{l}\text { Without } \\
(06: 15)\end{array}$ \\
\hline $\begin{array}{l}\text { Fourth } \\
\text { book }\end{array}$ & "TON KOTO TON" & $\begin{array}{l}\text { Written by Estuko Bushika } \\
\text { Illustrate by Shigeki Suezaki }\end{array}$ & $\begin{array}{l}\text { Without } \\
(04: 30)\end{array}$ & $\begin{array}{l}\text { With } \\
(04: 30)\end{array}$ & $\begin{array}{l}\text { Without } \\
(04: 30)\end{array}$ & $\begin{array}{l}\text { With } \\
(05: 15)\end{array}$ \\
\hline
\end{tabular}

\section{Video Coding and Depend Variables}

Video Coding began when the reader opened the picture book and started to read then continued until the picture book completed. The video was divided into $15 \mathrm{~s}$ increments to elicit the rate of how often a set of variables occurred during that timeframe. We measured five different variables (attention to picture books, looking at mother, pointing at picture books, utterances, sitting on the cushion.): Attention to picture books: It was defined as the child looking at a picture book for $15 \mathrm{~s}$. Looking at mother: It was scored when the child looks at the mother at least once every $15 \mathrm{~s}$. Also, pointing at picture books and utterances was scored when these actions occurred at least once every $15 \mathrm{~s}$. Utterances: it was scored that children talk about a picture book. Sitting on the cushion: It was defined as the child sitting on the cushion for $15 \mathrm{~s}$. Coding was performed with the assistance of people not familiar with the contents of the experiment (hereinafter referred to naïve). The test on July 23, 2019, was analyzed by three people (author and two naïve) while the test on October 19, 2019, was analyzed by seven people (author and six naïve raters). And then we examined the agreement value between authors and naïve observers: attention to picture books of agreement value average is $88 \%$ (minimum/maximum values from $55 \%$ to $100 \%$ ), looking at the mother is $96 \%$ ( $\mathrm{min} / \mathrm{max}$ values from $61 \%$ to $100 \%$ ), pointing at picture books is $100 \%$ ( $\mathrm{min} / \mathrm{max}$ values from $91 \%$ to $100 \%)$, utterances is $96 \%(\mathrm{~min} / \mathrm{max}$ values from $75 \%$ to $100 \%$ ), and sitting on the cushion $95 \%$ ( $\mathrm{min} / \mathrm{max}$ values from $28 \%$ to $100 \%$ ), all of the agreement value average maintained at least $85 \%$ or higher. 


\subsection{Result}

Figure 3 shows average data of the percentage of $15 \mathrm{~s}$ intervals with Attention to picture books, sitting on the cushion, Looking at mother. We analyzed for haptic feedback factor (with vibration and without vibration) and order factor (the first half and the second half) using an ANOVA in each different variable. We found an interaction between haptic feedback factor and order factor in attention to picture books $[F(1,30)=9.272, p=.005]$. There is no measurable effect of haptic feedback $[F(1$, $30)=0.057, p=.813]$ and order $[F(1,30)=2.420, p=.130]$. We noticed children's attention to picture books reduced in the second half when there was no haptic feedback. Also, there was significant interaction in looking at mother $[F(1$, $30)=4.937, p=.034]$. There is no main effect of haptic feedback $[F(1,30)=0.080$, $p=.779]$ and order $[F(1,30)=2.564, p=.120]$. Looking at mother increased in the second half when there was no haptic feedback. Regarding sitting on the cushion, we noticed it decreased in the second half regardless of haptic feedback (first half vs second half $),[F(1,30)=15.498, p<.001]$. Also, utterance had the same result $(6 \%$ first half, $3 \%$ second half with haptic feedback condition and $7 \%$ first half, $4 \%$ second half, without haptic feedback condition), $[F(1,30)=5.094, p=.031]$. Additionally, most children did not point to the picture books. Only four children pointed to picture book during the vibrotactile sessions, and this behavior occurred only once during the normal storytelling. Finally, we got feedback from their parents by using a free-form questionnaire about differences in the child's behavior from the parent's perspective. Table 2 is categorized feedback from parents.
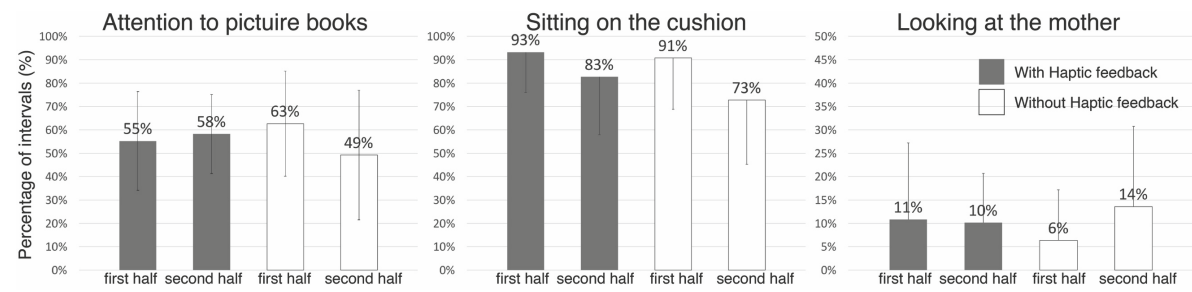

Fig. 3. Percentage of $15 \mathrm{~s}$ intervals with attention to picture books, sitting on the cushion, looking at the mother. Error bars is Standard Deviation

\section{Discussion}

We concluded the embodied experience with picture books using haptic feedback can reduced the declined children's attention to picture book when long storytelling with multiple children. Because, children's attention to picture books decreased in second half when normal storytelling condition but there was no change when with haptic feedback condition. Previous studies by Andreson et al. [14] that children watched TVcontent a longer time when they were concentrating. Ruff et al. [15] defined this concentration "Sustained attention", it is an important ability when they learn 
Table 2. Examples of feedback comments from parents

\begin{tabular}{|c|c|}
\hline Categories & Example of feedback \\
\hline Discovering the child's concentration & $\begin{array}{l}\text { - "she gets bored of long stories, but I confirmed } \\
\text { that she was concentrating because she thought it } \\
\text { was fun." (3 years } 8 \text { months old girls and mother) } \\
\text { - "She can't listen to storytelling too long at kids' } \\
\text { space, but today she listened to four books and I } \\
\text { was surprised (though during the third one she } \\
\text { seemed a little tired)." (3 years } 8 \text { months old girl } \\
\text { and mother) } \\
\text { - It was possible to return his attention to the picture } \\
\text { book by the sound and vibration when he was } \\
\text { distracted by toys. He won't come back from toys at } \\
\text { home. ( } 3 \text { years } 3 \text { months old boy and mother) } \\
\text { - He always pays attention to the details of the } \\
\text { picture, but today he was concentrating on getting } \\
\text { the whole story. (3 years } 5 \text { months boy and mother) }\end{array}$ \\
\hline $\begin{array}{l}\text { Discovering children's positiveness } \\
\text { through story-telling experiences }\end{array}$ & $\begin{array}{l}\text { - Normally he is shy and never leaves from me, but I } \\
\text { was surprised because he sat alone on the cushion } \\
\text { (3 years and } 0 \text { months boy/mother) } \\
\text { He is such a baby, so I expected him get on my knees, } \\
\text { but I was surprised when he returns to cushion } \\
\text { himself. (3 years } 7 \text { months boy and mother) }\end{array}$ \\
\hline Discovery of children's sharing & $\begin{array}{l}\text { - I was impressed when she looked at me sitting } \\
\text { behind her when the cushion vibrated. (4 years } 7 \\
\text { months girl and mother) }\end{array}$ \\
\hline
\end{tabular}

something in a school environment. Weighrt et al. [16] reported that continuous TVcontents helped to language acquisition, it can say that focus attention to subjects affects the child's process of knowledge. The value of "seating on the cushion" decreased second half time in both conditions. Because, it is conceivable that the children were listening to the picture book for a longer time than usually storytelling for the experiment. But Fig. 4 shows it recovered slightly with haptic feedback condition in the third book and fourth book. Also, we could observation that children who began to walk around kid space at third book normal storytelling, but they returned to their seat when fourth book by haptic feedback because children noticed that cushion was vibrating. In other words, it was possible to recover children's attention by haptic feedback. Additionally, this system might be more effective for children who normally have little ability to pay attention to picture books as it showed a significant shift in the child's behavior. Also, we could get these comments from parents that "she gets bored of long stories, but I confirmed that she was concentrating because she thought it was fun (3 years 8 months old girls and mothers)." And yet another, "She can't listen to storytelling too long at kids' spaces, but today she listened to four books and I was surprised (though during the third one she seemed a little tired) (3 years 8 months old girl and mother)." These comments support our results. We predicted the children's behavior that looking at mother occurred when children wanted to tell their mother 
about a picture book. It was occurred when first half and second half. However, it increased in the second half with no feedback. It was also observed that children then went to their mother after performing this behavior. Therefore, it seems that the behavior has two meaning: a sharing picture book interest and an expression of boredom. It is need to more detailed to measure these behaviors separately.
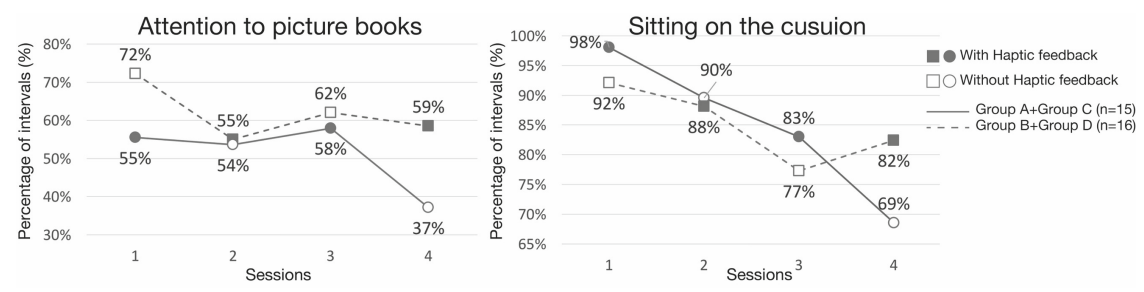

Fig. 4. Compared to order with or without haptic feedback

\section{Conclusion}

In this study, we aimed to design experience to grab children's attention to picture books when multiple children listen to storytelling together. Then we developed the Kinder "BURU BURU" cushion which multiple children can experience the world of picture books using their body. And we investigated the effects of our system using haptic feedback to use behavior analyzed method. As a result of experiment that we confirmed that our system can reduced the declined children's attention to picture book when long storytelling with multiple children. However, we found that the effect of the group experience was not enough to variables the children looking at mother. During the experiment, there were situations where children looked at each other who participated with friends. It is the possibility that more behavior will lead to joint attention. In the future, we would like to more clarify the effects of a group experience to storytelling, our system will be using continuous such as the environment where children know each other. Also, we believed that this method can helped other group work like elderly activity.

\section{References}

1. Ninio, A., et al.: The achievement and antecedents of labelling. J. Child Lang. 5(1), 1-15 (1978)

2. Snow, C.E., et al.: Routines in mother-child interaction. In: The language of Children Reared in Poverty, pp. 53-72. (1982)

3. Wilson, S.: The "Gifts" of Friedrich Froebel. J. Soc. Archit. Hist. 26(4), 238-241 (1967)

4. Montessori, M.: The Montessori Method. Transaction Publishers, Piscataway (2013)

5. Tudge, J.R., et al.: Vygotsky, Piaget, and Bandura: perspectives on the relations between the social world and cognitive development. Hum. Dev. 36(2), 61-81 (1993) 
6. Bruner, J.: From joint attention to the meeting of minds: an introduction. In: Joint attention: Its Origins and Role in Development, pp. 1-4 (1995)

7. Edwareds, C., et al.: The Hundred Languages of Children. Ablex Publishing Corporation, Norwood (1993)

8. Boston Children's Museum. http://www.bostonchildrensmuseum.org/

9. Iverson, J.M., et al.: What's communication got to do with it? Gesture in children blind from birth. Dev. Psychol. 33(3), 453 (1997)

10. Wakefield, E., et al.: Gesture helps learners learn, but not merely by guiding their visual attention. Dev. Sci. 21, e12664 (2018)

11. Antle, A.N., et al.: Hands on what? Comparing children's mouse-based and tangible-based interaction. In: International Conference on Interaction Design and Children (2009)

12. Yannier, N., et al.: FeelSleeve: haptic feedback to enhance early reading. In: Annual ACM Conference on Human Factors in Computing Systems, ACM 2015, pp. 1015-1024. (2015)

13. Zhao, S., et al.: Using haptic inputs to enrich story listening for young children. In: International Conference on Interaction Design and Children, ACM 2015, pp. 239-242 (2015)

14. Anderson, D.R., Levin, S.R.: Young children's attention to "Sesame Street". Child Dev. 47, 806-811 (1976)

15. Ruff, H.A., Capozzoli, M., et al.: Age, individuality, and context as factors in sustained visual attention during the preschool years. Dev. Psychol. 34(3), 454 (1998)

16. Wright, J.C., et al.: The relations of early television viewing to school readiness and vocabulary of children from low-income families: the early window project. Child Dev. 72 (5), 1347-1366 (2001)

17. Cingel, D., et al.: How parents engage children in tablet-based reading experiences: an exploration of haptic feedback. In: ACM Conference on Computer Supported Cooperative Work and Social Computing, pp. 505-510. (2017)

Open Access This chapter is licensed under the terms of the Creative Commons Attribution 4.0 International License (http://creativecommons.org/licenses/by/4.0/), which permits use, sharing, adaptation, distribution and reproduction in any medium or format, as long as you give appropriate credit to the original author(s) and the source, provide a link to the Creative Commons license and indicate if changes were made.

The images or other third party material in this chapter are included in the chapter's Creative Commons license, unless indicated otherwise in a credit line to the material. If material is not included in the chapter's Creative Commons license and your intended use is not permitted by statutory regulation or exceeds the permitted use, you will need to obtain permission directly from the copyright holder.

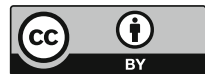

